\title{
Review Editor Introduction
}

\author{
Jeffrey C. Isaac
}

V ith this issue, we are pleased to initiate the practice of a Review Editor Introduction. As I noted in my initial Editorial Statement a few issues ago, the job of review editor is a weighty one, involving some complex judgments. The choices regarding review assignments, pairings, and such that I make-with the advice of my terrific team of assistants - impact individual authors and the profession as a whole. Given our desire to use the review section to create interesting dialogues and new conversations, we have decided that an editor's introduction could be useful, in identifying certain inter and intra subfield connections and in introducing special features or symposia.

This issue contains our most ambitious symposium to date, on the topic of suicide bombing and, more generally, terrorism. In recent years, this topic has been much in the news and on the minds of policymakers and journalists. As many recent scholarly publications - including the three books under review-indicate, it is a topic that has also gained the attention of political scientists. I thought that both the topic and the books were important and worth discussing in an intellectually serious way, and that it would enhance scholarship and intelligent public discourse to invite a range of scholars, from a variety of approaches and methodologies, to comment on the subject. The symposiasts_-Karen Rasler, Gilles Kepel, David Laitin, Eli Berman, Ian Shapiro, and Roxanne Eubenare all scholars who have produced important work on related topics. Together they demonstrate that political science is a pluralistic discipline capable of illuminating important public issues from multiple angles. The symposiasts agree that suicide bombing is a social and political phenomenon amenable to serious and disciplined analysis using the methods and concepts developed in connection with other political phenomena. They also agree that such inquiry can contribute to public discourse by getting beyond some of the simplistic and sensationalistic assertions often made in the media. Yet at the same time, they offer different perspectives on the question of what are the appropriate methods and concepts for understanding political phenomena. Some of them are comfortable with the rational-choice approaches that seem to animate much recent scholarship on suicide bombing. Others offer more "interpretive" perspectives. Indeed, the symposium makes clear that the very basic terms with which we describe the phenomena in question_— "suicide bombing," "terrorism"are themselves theory-laden and contentious.

The symposium honors the books under review by subjecting them to sincere and constructive criticism. A few questions loom large in the commentaries: What are the strengths and limits of a rational-choice approach to suicide bombing? In what ways might strategic perspectives be further developed and extended by scholars drawn to these approaches? What are the advantages and disadvantages of constructing suicide bombing as a general topic of analysis or "dependent variable," as opposed to a more contextualized and culturally specific interest in kinds of "suicide terror," particularly in recent forms of Islamist suicide terror? One question that I posed to the symposiasts in my charge did not receive much attention, and that is what we might call the "moral" question. In short, does the topic of suicide bombing present any special ethical questions or implicate general issues related to "objectivity" and "value neutrality" in political science. My own view is that it does-which is why I posed the question. The symposium makes clear that political science can have a sobering effect on public understanding, by presenting analysis and insight rather than moralism. I also think that there are multiple ways to "normalize" violence by studying it, and that much recent social scientific discussion of suicide bombing exemplifies this issue. It is one that will no doubt receive attention as scholarly discussions continue. In any case, it is not an issue that is distinctive to suicide bombing (as opposed to other forms of violence or other topics of political analysis more broadly, which pose the same questions, about which our colleagues will no doubt continue to disagree, hopefully in healthy and productive ways).

In this issue, readers will also find a number of more "conventional" book reviews that relate to the symposium and that also raise some broader themes worthy of note. A number of books under review treat issues directly related to terrorism and the understanding of violence, especially Emilio Gentile's Politics as Religion, Janet Afary and Kevin B. Anderson's Foucault and the Iranian Revolution: Gender and the Seductions of Islamism, Paul Brass's 
The Production of Hindu-Muslim Violence in Contemporary India, and Ivan Arreguin-Toft's How the Weak Win Wars: A Theory of Asymmetric Conflict. Another set of related books deals with the topic of social movements, and particularly the development of transnational movements (the transnational or diasporic and social movement dimensions of terror networks are increasingly studied). Particularly of note are Donatella della Porta et al.'s Globalization from Below: Transnational Activists and Protest Networks, David Romano's The Kurdish Nationalist Movement: Opportunity, Mobilization and Identity, and Lee Ann Banaszak's anthology The U.S. Women's Movement in Global Perspective. Finally, four books featured in this issue directly raise important methodological questions about the practice of political science: Lisa Anderson's Pursuing Truth, Exercising Power: Social Science and Public Policy in the Twenty-First Century, Alexander L. George and Andrew Bennett's Case Studies and Theory Develop- ment in the Social Sciences, Keith Topper's The Disorder of Political Inquiry, and Philip E. Tetlock's Expert Political Judgment: How Good Is It? How Can We Know? We have also begun to offer certain multiple reviews a bit more space in order to develop specific themes of note. We are thus pleased to feature John Zysman's review of books on the theme of inequality and social policy, a topic of broad relevance in political science in this globalizing era.

One more thing. Academic journals such as this one, like so much else in the academy, can flourish only because of the hard and inspired work of graduate students who are called assistants but who typically do much more than merely assist. I am thus happy to recognize the dedicated work of my terrific staff of so-called assistants: Shanna Dietz (Comparative Politics), James Moskowitz (International Relations), Margot Morgan (Political Theory and review essays/symposia), and Rebekah Tromble (American Politics). 